Experience Report \title{
Obstetrical nurse development at Universidade de
Pernambuco, Brazil: a 35-year history
}

\author{
Formação da enfermeira obstetra na Universidade de Pernambuco, Brasil: 35 anos de história
}

Formación de la enfermera obstétrica en la Universidad de Pernambuco- Brasil: 35 años de bistoria

\author{
Arabela Antônia Nery de Melo Costa ${ }^{1}$, Kátia Rejane Vergueiro César ${ }^{2}$, Janine \\ Schirmer ${ }^{3}$, Márcia Maia Ferreira Tavares ${ }^{4}$
}

\begin{abstract}
Aiming at presenting the social, professional, legal and educational contexts which have founded the curriculum reforms in the Obstetrical Nursing major and specialization, the 35-year teaching history, experienced in the Nossa Senhora das Graças Nursing School of the Universidade de Pernambuco, in the city of Recife, Brazil, built based on documental analysis. The syllabuses of four reformulations performed in the Obstetrical Nursing major and two syllabuses of specialization courses in the same area, with explanation of the guiding framework of the reformulations concerned with humanized attention towards labor and birth. The historical evolution of this experience demonstrates how the university can build the social awareness role in the faculty, which can improve life quality of puerperae and their children, awarding them the right to perform their citizenship.
\end{abstract}

Keywords: Nursing education; Nursing history; Nursing school; Obstetrical nursing

\section{RESUMO}

Com o objetivo de apresentar os contextos social, profissional, legal e educacional que serviram de base para as reformas curriculares na habilitação e especialização em Enfermagem Obstétrica, relata-se a história de 35 anos de ensino, vivenciados na Faculdade de Enfermagem Nossa Senhora das Graças da Universidade de Pernambuco, Recife, Pernambuco, Brasil, construída com base em análise documental. São apresentadas as grades curriculares de quatro reformulações procedidas na habilitação de Enfermagem Obstétrica e duas grades curriculares dos cursos de especialização na mesma área, explicitando-se a conjuntura norteadora dessas reformulações em direção a uma atenção humanizada ao parto e ao nascimento. A evolução histórica dessa experiência vem demonstrar como pode a Universidade formar no corpo docente a consciência social de seu papel na melhoria da qualidade de vida de gestantes e conceptos, resgatando-lhes o direito do exercício da cidadania neste aspecto.

Descritores: Educação em enfermagem; História da enfermagem; Escolas de enfermagem; Enfermagem obstétrica

\section{RESUMEN}

Con el objetivo de presentar los contextos social, profesional, legal y educativo que sirvieron de base para las reformas curriculares en la habilitación y especialización en Enfermería Obstétrica, se relata la historia de 35 años de enseñanza, vivenciados en la Facultad de Enfermería Nuestra Señora de las Gracias de la Universidad de Pernambuco, Recife, Pernambuco - Brasil, construída teniendo como base el análisis documental. Son presentados los planes curriculares de cuatro reformulaciones realizadas en la habilitación de la Enfermería Obstétrica y dos planes curriculares de los cursos de especialización en la misma área, explicándose la conyuntura que orientaron esas reformulaciones en dirección a una atención humanizada del parto y nacimiento. La evolución histórica de esa experiencia viene a demostrar cómo puede la Universidad formar en el cuerpo docente la conciencia social de su papel en la mejora de la calidad de vida de gestantes y conceptos, rescatándoles el derecho al ejercicio de la ciudadanía en ese aspecto.

Descriptores: Educación en enfermería; Historia de la enfermería; Escuelas de enfermería; Enfermería obstétrica

\footnotetext{
${ }^{1}$ Ph.D., Adjunct Professor of the Obstetrical Nursing Discipline at Universidade de Pernambuco - UPE - Recife, (PE), Brazil.

${ }^{2}$ Master of Science, Assistant Professor of the Surgical Clinic Discipline at Universidade de Pernambuco - UPE - Recife, (PE), Brazil.

${ }^{3}$ Professor and Chairwoman of the Obstetrical Nursing Discipline at Universidade Federal de São Paulo - UNIFESP - São Paulo, (SP), Brazil.

${ }^{4}$ Master of Science, Assistant Professor of the Emergency and Trauma Discipline at Universidade de Pernambuco - UPE - Recife, (PE), Brazil.
} 


\section{INTRODUCTION}

The educational process is characterized by its history, which may be retrieved from documents or verbal communications, when documents are not available. Regardless of the way the fact is retrieved, it is imperative to maintain the institution memory, which is reflected here, all the construction processes and knowledge improvement of obstetrical nursing

The Nossa Senhora das Graças Nursing School (FENSG), founded on 01/08/1945 by the São Vicente de Paula Charity Daughters Congregation ${ }^{(1)}$, had its major recognized by the Ministry of Education and Culture with decree no. 27281, of 30/09/1949(1) and had its first graduation in 1950*. It became part of Universidade Estadual de Pernambuco(UPE), on 28/ $03 / 1967$ and was the first undergraduate course in Nursing in the Pernambuco and the second in the northeast*.

For the development of the FENSG major, there was the association of the model proposed by A. Flexner and the Florence Nathingale's principles. Its characteristics were: solid background in basic sciences in the first year of the course; little emphasis on health promotion and protection; centralization of the aspects in individual medical care; learning valorization in the hospital setting; ambulatory accompanying solely in cases that required hospitalization and great workload in the practices*.

Since the 1970s, the university educational framework has suffered modifications. The Brazilian Nursing Association, by regional seminars, has performed a situational diagnosis, identifying two problems: the profile of the nursing professional did not meet the market needs due to the lack of specialists in several professional fields, leading to loss of opportunities in the market place. By contrast, there was not modification in the focus of attention of the hospitalocentric model for preventive actions ${ }^{(2)}$.

In this context, under the direction of sister Neli Lima Soares, there was the start of a movement commited to the academic changes, contemplating the demands of the University Reform for the implantation of a new syllabus in 1972*.

\section{THE DEGREE IN OBSTETRICAL NURSING}

The new syllabus structured the Obstetrical Nursing degree with two semesters of specific content and 840hour workload. The pre-requisite was the approval in the basic (in three semesters) and professional cycles (in

*These data were retrieved from the FENSG-UPE archive. four semesters) of the Nursing degree. The degree in Obstetrical Nursing was coordinated by professor Francisca Judith Veras de Souza (Sister Filomena), its idealizer. Until 1979, the faculty was made up of this professor and professor Pedro Alves Pereira da Silva Filho, who counted on the support of nurses and doctors, voluntary preceptors of Professor Monteiro de Morais Maternity*. The first class graduated on the 17th of December, $1972^{* *}$ (Table 1).

The major implantation was based on the need of curative services area, hospitalocentric, with interventions in maternities and obstetrical clinics. It was technicist, focused on the content of the given disciplines, with emphasis on the course conclusion ${ }^{(2)}$.

The UPE Professor Monteiro de Moraes Maternity, from 1977 to 1992, developed a Home Midwives Control Program, coordinated by the nurse Diná Teodósio da Silva, which held three objectives: provision of home labor material; midwife training to assist home labor; and guidance to notify home labor by means of a handwritten childbirth declaration, for obtaining a birth certificate at the Civil Register Office. All these actions were part of the Obstetrical Nursing students' activities***.

Since 1979 first semester, there was been greater requirements for the major conclusion: it entails the students present and hand in an essay. The faculty was amplified with the arrival of invited professors Elizabeth de Souza Amorim (March of 1980), Arabela Antônia Nery de Melo Costa (August of 1982), Ironaldo da Silva Veras (March of 1985) and Gustavo Bezerra Serra Sêca (June of 1986), and others from 1987* on.

In the first curricular reform, in 1984, the workload was redistributed. The workload of the theoretical disciplines - Normal, Pathological and Neonatal Obstetrics* -, was reduced. In order to meet the health care and administrative requirements of the market, there was an increase in the managerial activities in the obstetrical center, with the disciplines Administration IV, ministered by professors Maria Vanda de Araújo and Kátia Rejane Vergueiro César**** (Table 1). The theoretical disciplines Obstetrical and Gynecological Nursing was created with a 30-hour workload and 300hour practice for prenatal, labor and after-labor intervention, being 50 labors compulsory****.

In the second curricular reform, in 1991, there was an increase in the major total workload from 840 hours to

\footnotetext{
** Verbal information of nurse Maria Vanda de Araújo (Sister Vanda), Professor Emeritus of the Nossa Senhora das Graças Nursing School of the Universidade de Pernambuco and alumni of of the first class to hold a degree in Obstetrical Nursing in this University. ${ }^{* * *}$ Verbal information of nurse Diná Teodósio da Silva, Professor Emeritus of the Nossa Senhora das Graças Nursing School of the Universidade de Pernambuco and coordinator of the Home Midwives Control Program.
} 
930 hours. The methodological discipline Scientific Methodology was implanted, proposed and ministered by professor Arabela Antônia Nery de Melo Costa, for technical operationalization of the end-of-term research planning****. The theoretical discipline Obstetrical and Gynecological Nursing was extinguished, with same workload being dedicated exclusively to Gynecology, and greater internship workload for a healthier or less risky pregnancy. Greater workload was dedicated to the Normal and Neonatal Obstetrics internship (Table 2) ****.

The main objective of the workload increase, in the second reform, was to broaden the pedagogical approach, making the students associate the epidemiological and managerial knowledge and the practice of the clinical method in all the stages in the gravidity-puerpera cycle. The students began to act in the prevention of mother-child health problems****.

In 1993, the third change in the syllabus took place. There was a workload increase in the Scientific Methodology discipline so as to provide assistance to the academic production (Table 2 )*****.

In 1987, the Brazilian Nursing Association initiated in the whole country the new discussion process about the nursing major teaching which resulted in 1994 in a curricular reformulation proposal, approved by government regulation no. 1721, of 15/12/1994, from the Ministry of Education and Culture ${ }^{(3)}$. The reformulation consisted on extinguishing some classes to ensure a complete nurse formation, without including premature specializations.

The FENSG-UPE, accompanying the curricular reformulation process, promoted the fourth and last alteration in the Obstetrics workload, for the 1994-2000 period, interval necessary for the first general nursing class to graduate under the new undergraduate proposal, whose technical-scientific improvement in Obstetrics began to be done at the specialization level*. Thus, the new curricular proposal sought to integrate to undergraduates the content of the degrees. In order not to create a dichotomy between prematurely specialized students and general students, the FENSG incorporated specific theoretical contents to undergraduates, enabling the workload reduction from 1050 hours to 930 hours (Table 2)*.

In the 1972-2000 period, 324 obstetric nurses graduated in this modality, whose characteristics were: $316(97.5 \%)$ were females and $8(2.5 \%)$ were males, corresponding to a 39.5:1 ratio; regarding nationality, 1 $(0.3 \%)$ female nurse was Portuguese and $323(99.7 \%)$ Brazilians. The origin distribution was: $1(0.3 \%)$ from the North Region (AM), 1 (0.3\%) from the South Region (RS), $6(1.8 \%)$ from the Southeast Region (SP, RJ and

Table 1 - Syllabus of the degree in Obstetrical Nursing at FENSG-UPE. Recife, PE, 1972-1984

\begin{tabular}{lrrrrrr}
\hline \multirow{2}{*}{ Disciplines } & \multicolumn{3}{c}{ 1972 } & & \multicolumn{2}{c}{$\mathbf{1 9 8 4}$} \\
\cline { 2 - 7 } & Theoretical & Internship & Total & Theoretical & Internship & Total \\
\hline Normal Obstetrics & 160 & 260 & 420 & 30 & 80 & 110 \\
Pathological Obstetrics & 40 & 60 & 100 & 30 & 70 & 100 \\
Neonatal Obstetrics & 40 & 80 & 120 & 30 & 80 & 110 \\
Obstetrical and Gynecological Nursing & - & - & - & 30 & - & 30 \\
Gynecological Nursing & 10 & 90 & 100 & - & 80 & 80 \\
Obstetrical Center & - & - & - & - & 300 & 300 \\
Obstetrical Center Management & 20 & 80 & 100 & 30 & 80 & 110 \\
Scientific Methodology & - & - & - & - & - & - \\
\hline Total & $\mathbf{2 7 0}$ & $\mathbf{5 7 0}$ & $\mathbf{8 4 0}$ & $\mathbf{1 5 0}$ & $\mathbf{6 9 0}$ & $\mathbf{8 4 0}$ \\
\hline
\end{tabular}

Table 2 - Syllabus of the degree in Obstetrical Nursing at FENSG - Recife, PE, 1991 to 1994.

\begin{tabular}{|c|c|c|c|c|c|c|c|c|c|}
\hline \multirow{2}{*}{ Disciplines } & \multicolumn{3}{|c|}{1991} & \multicolumn{3}{|c|}{1993} & \multicolumn{3}{|c|}{1994} \\
\hline & Theoretical & Internship & Total & Theoretical & Internship & Total & Theoretical & Internship & Total \\
\hline Normal Obstetrics & 30 & 102 & 132 & 30 & 102 & 132 & 30 & 90 & 120 \\
\hline Pathological Obstetrics & 30 & 60 & 90 & 30 & 60 & 90 & 30 & 60 & 90 \\
\hline Neonatal Obstetrics & 30 & 100 & 130 & 30 & 100 & 130 & 30 & 60 & 90 \\
\hline Gynecological Nursing & 30 & 98 & 128 & 30 & 98 & 128 & 30 & 60 & 90 \\
\hline Obstetrical Center & - & 300 & 300 & - & 300 & 300 & & 300 & 300 \\
\hline Obstetrical Center Management & 30 & 90 & 120 & 30 & 90 & 120 & 30 & 60 & 90 \\
\hline Scientific Methodology* & 30 & - & 30 & 30 & $120^{*}$ & 150 & 30 & $120 *$ & 150 \\
\hline Total & 180 & 750 & 930 & 180 & 870 & 1050 & 180 & 750 & 930 \\
\hline
\end{tabular}

Note: * The workload of the Research Methodology discipline refers to the practice in elaborating the essay.

\footnotetext{
**** Verbal information of nurse Maria Augusta Gomes (Sister Rosalie), Professor Emeritus of the Nossa Senhora das Graças Nursing School of the Universidade de Pernambuco, alumni of the first undergraduate nursing class at FENSG-UPE.

****** These data were retrieved from the FENSG-UPE archive.
} 
MG) and 315 (97.2\%) from the Northeast Region, and $59(18.7 \%)$ from other Northeast states (BA, AL, RN, $\mathrm{PB}, \mathrm{SE}, \mathrm{CE}, \mathrm{MA}$ and PI) and 256 (81.3\%) from Pernambuco $^{(4)}$.

SPECIALIZATION IN OBSTETRICAL NURSING AND THE SOCIAL GAINS

The specialization in Obstetrical Nursing resulted from the conjunction of several favorable factors. In 1999, the Women Health Technical Area of the Ministry of Health launches the construction policy of a "New Model of Women Health Care in Brazil" integrated by the Humanization Programs in Prenatal and Birth ${ }^{(5)}$ and the Vaginal Delivery Centers ${ }^{(6)}$, among others. To promote its implantation in the whole country, this Ministry began to support financially the specialization courses in Obstetrical Nursing, with partnerships of the State and Municipal Health Secretariats and Higher Education Institutions, involving them with the Public Health System (PHS), as forming organizations ${ }^{(7-8)}$.

The financing is conditioned to compliance by criteria related to the teaching institution, to the selective process, to the syllabus organization and to the evaluation process $^{(8)}$. The selective process for 15 to 20 vacancies should meet the following demands: $80 \%$ of the targetclientele constituted of nurses from the PHS ambulatory and hospital network, including units of the Family Health Program, at least 10 year-long permanence in the public service after graduation and liberation of the professional, by employer, for at least six months, not exceeding 12 months, to perform the curricular activities corresponding to a 460-600 hour workload ${ }^{(8)}$.

Regarding the curricular structure, the guidelines state that the course should contain theme area or disciplines such as Fundamental Obstetrics, Obstetrical Nursing and Perinatal Nursing, with a third of theoretical workload and two thirds dedicated to practical activities in health institutions. The syllabus should contemplate all the government regulations and laws of the New Model of Women Health Care ${ }^{(8)}$.

The criterion to evaluate the students should prioritize technical skills and safety in assistance performance, as stated by $\mathrm{CNE} / \mathrm{CES} \mathrm{n}^{\circ} .1 / 2001$ resolution $^{(9)}$. Hence, a minimum of 20 labors should be performed with complete accompanying of the prelabor (using partogram), labor and postlabor. Also, 15 newly-born consultations in the labor room and 15 prenatal consultations ${ }^{(10)}$, in compliance with the ABENFO/98 criteria.

As the FENSG-UPE complied with all the administrative requirements, conducted negotiations with the Ministry of Health. A political-pedagogical project of the course was built, prioritizing basic care of the care model for labor and childbirth humanization in PHS. Less interventionist and iatrogenic obstetrical assistance was sought and there was priority in reducing the mother and perinatal morbi-mortality ${ }^{(11)}$.

The two first courses in 2001 and 2003 had the same syllabus ${ }^{(11)}$. In 2005, there was the need of reducing and redistributing workload so as to meet two contingencies. The first derived from the need of mitigating costs by reducing the Ministry of Health specialization budget ${ }^{(12)}$. The second was to make the essay elaboration compatible with the students time availability. In 2005, it was possible to increase the number of institutions where there were internships. Thus, the students were able to conclude the requirements of labor assistance in a shorter time. The workload was meant to compensate the hardship in elaborating the essay (Table 3).

In Pernambuco, three specialization courses were ministered in the 2000-2006 period. The two first ones were funded by the Ministry of Health and the third by the Pan-American Health Organization, through the Ministry, forming 46 specialists, all of them females, whose origin is shown in Table $4^{(13)}$.

Regarding the specialization classes constitution, some comments should be made about the selective process and nurses dropping-out. For the selective process, the

Table 3 - Syllabus of the specialization course in Obstetrical Nursing at FENSG-UPE, according to workload and year of modification. Recife - PE, 2001 to 2005

\begin{tabular}{|c|c|c|c|c|c|c|}
\hline \multirow{2}{*}{ Disciplines } & \multicolumn{3}{|c|}{2001} & \multicolumn{3}{|c|}{2005} \\
\hline & Theoretical & Internship & Total & Theoretical & Internship & Total \\
\hline Fundamental Obstetrics & 45 & 60 & 105 & 45 & 60 & 105 \\
\hline Obstetrical Nursing & 60 & 210 & 270 & 45 & 180 & 225 \\
\hline Perinatal Nursing & 30 & 60 & 90 & 30 & 30 & 60 \\
\hline $\begin{array}{l}\text { Right to Citizenship/Gender, Sexuality and Women } \\
\text { Health }\end{array}$ & 45 & - & 45 & - & - & - \\
\hline Scientific Research Methodology ${ }^{1}$ & 30 & $60^{1}$ & 90 & - & - & - \\
\hline $\begin{array}{l}\text { Research Methodology Applied to Sexual and } \\
\text { Reproductive Women Health }{ }^{2}\end{array}$ & - & - & - & 30 & $120^{2}$ & 150 \\
\hline Total & 210 & 390 & 600 & 150 & 390 & 540 \\
\hline
\end{tabular}

Note: ${ }^{1}$ The workload of the Research Methodology discipline refers to the practice in elaborating the essay. ${ }^{2}$ The workload of the Research Methodology Applied to Sexual and Reproductive Women Health discipline refers to the practice in elaborating the essay. 
Table 4 - Characteristics of the specialization course in Obstetrical Nursing - Recife-, PE, 2001-2006

\begin{tabular}{|c|c|c|c|}
\hline \multirow{2}{*}{ Characteristics } & \multicolumn{3}{|c|}{ Number of Groups } \\
\hline & First & Second & Third \\
\hline Financial Support & Ministry of Health & Ministry of Health & OPAS \\
\hline Period & $01 / 08 / 01$ to $30 / 07 / 02$ & $10 / 02 / 03$ to $08 / 08 / 03$ & $25 / 04 / 05$ to $30 / 02 / 06$ \\
\hline Workload & 600 & 600 & 540 \\
\hline Number of vacancies* & 20 & 16 & 16 \\
\hline Number of students who finished & 20 & 13 & 13 \\
\hline Distribution by City (no.) & 10 & 7 & 8 \\
\hline Arcoverde & - & - & 1 \\
\hline Caruaru & - & - & 1 \\
\hline Correntes & 1 & - & - \\
\hline Custódia & - & - & 1 \\
\hline Dormentes & 1 & 1 & - \\
\hline Garanhuns & - & - & 1 \\
\hline Goiânia & - & - & 1 \\
\hline Limoeiro & - & - & 1 \\
\hline Mirandiba & 1 & 1 & - \\
\hline Olinda & 1 & 1 & - \\
\hline Orocó & 1 & - & 1 \\
\hline Paulista & 1 & 1 & - \\
\hline Recife & 11 & 7 & 6 \\
\hline ** CISAM-UPE & 4 & 2 & 1 \\
\hline ** Professor Barros Lima Policlinic and Mat. & 2 & 2 & 2 \\
\hline ** Agamenon Magalhães Hospital & 3 & - & - \\
\hline ** Professor Barros Lima Policlinic and Mat. & 1 & - & - \\
\hline ** Barão de Lucena Hospital & 1 & 2 & - \\
\hline ** IMIP & - & 1 & 2 \\
\hline ** State Health Secretariat & - & - & 1 \\
\hline Serinhaém & 1 & - & - \\
\hline Tupanatinga & 1 & 1 & - \\
\hline Verdejante & 1 & - & - \\
\hline Vertentes & - & 1 & - \\
\hline
\end{tabular}

Note: ${ }^{*}$ In all the groups, an extra vacancy was offered as reserve for eventual dropping-out

Health State Secretariat would send to the FENSG-UPE nurses who were working in cities contemplated with the State Project "Vaginal Delivery Centers for Pernambuco". Then, they would be subjected to analysis and interview. When there were vacancies available, nurses from other cities were sent. Thus, nine cities, not participating in the project, and eight cities, participating in the project, were contemplated.

The dropping-out of three students, in the second and third course is due to the fact they were not allowed to leave their jobs and quit working.

Another social gain of the degree and the specialization courses in Obstetrical Nursing was the resulting academic production. In the 1979-2006 period, there were 289 essays, $243(83.5 \%)$ of them were about to hold a degree (representing $89.8 \%$ of the 324 undergraduates) and $46(16.5 \%)$ belonging to specialization students (corresponding to $100 \%$ of the students). Among the 289 essays, the tackled topics were: norm manuals and maternity sectors techniques (39.6\%);

\section{REFEFERENCES}

1. Brasil. Decreto n 27281 , de 30 de setembro de 1949. Ministério da Educação. Concede reconhecimento ao gynecological nursing (33.3\%); prenatal (9.4\%); labor $(7.3 \%)$; puerperium $(6.2 \%)$ and breast-feeding $(4,2 \%)^{(13)}$.

Throughout the 35-year formation of obstetrical nurses at FENSG-UPE, 370 nurses concluded the course, $324(87.6 \%)$ in the degree modality ${ }^{(4)}$ and 46 $(12.4 \%)$ in the specialization modality ${ }^{(13)}$.

\section{CONCLUSIONS}

The history retrieval of the obstetrical nurses formation at FENSG-UPE should not be seen only as a description of events which are characteristic of a teaching institution, but after all, as a social result of a university that has committed its faculty aiming at contributing to improving women and children life quality. It reflects the practical viability of an integrated work between the University and the Public Health System, designing a New Model of Women Health Care in Pernambuco, a partnership with the Ministry and the Health State and Municipal Secretariats.

Curso de Enfermagem da Escola de Enfermeiras Nossa Senhora das Graças do Recife. Diário Oficial da República 
Federativa do Brasil. Rio de Janeiro 1949 Out 6.

2. Brasil. Ministério da Educação e Cultura. Conselho Federal de Educação. Resolução n ${ }^{\circ} 4 / 72$, de 25 de fevereiro de 1972. Institui o currículo mínimo dos cursos de Enfermagem e Obstetrícia. Brasília: Diário Oficial da República Federativa do Brasil. Brasília (DF); 1972 Jul 6.

3. Brasil. Ministério da Educação e Desporto. Portaria n ${ }^{\circ}$. 1.721, de 15 de dezembro de 1994. Dispõe sobre a formação do Enfermeiro, que será feita em curso de graduação e cumprirá os mínimos de conteúdo e de duração fixados pela presente Portaria. Diário Oficial da República Federativa do Brasil. Brasília (DF); 1994 Dez 16.

4. Costa AANM, Santos KB, Calixto MM. Enfermeiras obstetras egressas da Universidade de Pernambuco, Brasil: trajetória profissional. Estudo financiado pelo Fundo de Desenvolvimento a Pesquisa e Extensão da UPE (FDPEUPE). In: Seminário de Pesquisa da UPE. 2006: Out 2030; Recife. Anais. Recife: UPE; 2006.

5. Brasil. Ministério da Saúde. Portaria $n^{\circ} .569$, de $1^{\circ}$ de junho de 2000. Institui o Programa de Humanização no Prénatal e Nascimento, no âmbito do Sistema Único de Saúde. Diário Oficial da República Federativa do Brasil. Brasília (DF); 2000 Jun 8.

6. Brasil. Ministério da Saúde. Portaria n . 985/GM, de 5 de agosto de 1999. Dispõe sobre Criar o Centro de Parto Normal - CPN, no âmbito do Sistema Único de Saúde/ SUS, para o atendimento à mulher no período gravídicopuerperal. Diário Oficial da República Federativa do Brasil. Brasília (DF); 1999 Ago 6.

7. Brasil. Ministério da Educação e Cultura. Conselho Nacional de Educação. Câmara de Educação Superior. Resolução CES n .3 de 5 de outubro de 1999. Fixa condições de validade dos certificados de cursos presenciais de especialização. Diário Oficial da República Federativa do Brasil. Brasília (DF); 1999 Out 7.

8. Brasil. Ministério da Saúde. Secretaria de Políticas de Saúde. Área Técnica de Saúde da Mulher. Comitê de Especialistas em Enfermagem Obstétrica: Diretrizes para elaboração de projetos de cursos de especialização em enfermagem obstétrica. Brasília: Ministério da Saúde; 2000.

9. Brasil. Ministério da Educação. Conselho Nacional de Educação. Câmara de Educação Superior. Resolução CNE/ CES n ${ }^{\circ} .1$, de 3 de abril de 2001. Estabelece normas para o funcionamento de cursos de pós-graduação. Brasília: Diário Oficial da República Federativa do Brasil. Brasília (DF); 2001 Abr 9.

10. Brasil. Conselho Federal de Enfermagem. Código de ética dos profissionais de enfermagem. Brasília, 1998. p. 17-21.

11. Costa AANM, Schirmer J, Santos SSC. The training of obstetric nurses in Pernambuco, Brazil: an experience report in the light of Morin's education for the future [CD-ROM]. In: 15th International Congress on Women's Health Issues and IV Congress on Obstretrics on Neonatal Nursing. 2004: Nov 7-10; São Pedro. Ribeirão Preto: EEPP/USP; 2004.

12. Brasil. Ministério da Saúde. Secretaria de Políticas de Saúde. Área Técnica de Saúde da Mulher. Comitê de Especialistas em Enfermagem Obstétrica: Diretrizes para elaboração de projetos de cursos de especialização em enfermagem obstétrica. Brasília: Ministério da Saúde; 2004.

13. Costa AANM, Ribeiro MCS, Santos FM, Schirmer J. A construção do conhecimento em enfermagem obstétrica na Universidade de Pernambuco. In: $9^{\circ}$ Congresso Brasileiro dos Conselhos de Enfermagem. 2006: Set 24-28; Porto Seguro. Livro de Resumos. Porto Seguro: COREN, 2006. 